\title{
KARAKTERISTIK PERLINDUNGAN HUKUM DEBITOR DALAM PENGUASAAN OBJEK JAMINAN FIDUSIA
}

\author{
Dwi Tatak Subagiyo \\ Fakultas Hukum, Universitas Wijaya Kusuma Surabaya \\ e-mail: tataksubagiyo@gmail.com \\ Endang Prasetyawati \\ Fakultas Hukum, Universitas 17 Agustus 1945 Surabaya \\ e-mail: endang_pras@untag-sby.ac.id
}

\begin{abstract}
ABSTRAK
Penelitian berjudul Karakteristik Perlindungan Hukum Debitor Dalam Penguasaan Objek Jaminan Fidusia dengan latar belakang bahwa adanya kebutuhan modal dari para pengusaha untuk tetap menjalankan usahanya. Modal digunakan meningkatkan kesejahteraan hidup, di samping usahanya tetap berjalan. Undang-Undang Nomor 42 Tahun 1999 tentang Jaminan Fidusia, dinyatakan terdapat perpindahan hak milik yaitu dari debitor (pemberi fidusia) ke kreditor (penerima fidusia), padahal kedudukan benda jaminan, tetap berada di tangan debitor. Berdasarkan pernyataan tersebut terdapat masalah yaitu: Bagaimana karakteristik perlindungan hukum debitor dalam menguasai objek jaminan fidusia; dan Bagaimana kedudukan hukum debitor dalam menguasai objek jaminan fidusia? Kesimpulan dari penelitian sebagai berikut: Pertama, karakteristik perlindungan hukum debitor dalam penguasaan objek jaminan fidusia, digunakan untuk memberikan perlindungan hukum debitor selama menguasai obyek jaminan fidusia, supaya tidak terjadi tindakan kesewenang-wenangan kreditor, atas penguasaan objek jaminan fidusia, karena dengan mendasarkan pada kepercayaan yang bersifat absolut belum dapat menjamin perlindungan hukum bagi debitor. Kedua, kedudukan hukum debitor dalam menguasai benda jaminan fidusia dalam posisi yang kuat, karena dalam hukum benda dinyatakan bahwa apabila seseorang menguasai benda bergerak maka seorang tersebut sebagai pemilik dari kebendaan bergerak tersebut, artinya seorang debitor dalam jaminan fidusia penguasaan benda sebagai bezitter, sekaligus berkedudukan hukum sebagai pemilik atau eigenaar.
\end{abstract}

Kata Kunci: karakteristik; fidusia; debitor; perlindungan hukum

\section{ABSTRACT}

Research entitled Characteristics of Legal Protection of Debtors Mastering the Object of Fiduciary Assurance against the background that there is a need for capital from entrepreneurs to keep running their business. Capital is used to improve the welfare of life, in addition to keeping his business running. Law Number 42 Year 1999 concerning Fiduciary Guarantee, there is stated transfer of ownership from debitor (fiduciary) to creditor (fiduciary recipient), whereas the position of collateral object remains in the hands of the debtor. Based on the statement there are problems that are: How the characteristics of the debtor's legal protection in mastering the fiduciary guarantee object; and How is the position of the debtor's law in mastering fiduciary security objects? The conclusions of the research are as follows: First, the characteristics of the debtor's legal protection control the object of fiduciary guarantee, is used to provide the debtor's legal protection in controlling the fiduciary security object, in order to avoid the arbitrary act of creditors, on the mastery of the fiduciary guarantee object, absolute nature can not guarantee legal protection for debtors. Second, the position of the debtor's law in controlling the fiduciary assurance object in a strong position, because in the law of the object stated that if a person controls the moving object then the person is the owner of the moving object, that is, a debitor in the fiduciary guarantee of possession as a bezitter, as owner or eigenaar.

Keywords: characteristics; fiduciary; debtor; legal protection 


\section{PENDAHULUAN}

Pada dasarnya hukum tidak dapat dipisahkan dari kehidupan manusia. hal ini dikarenakan pada saat kelahirannya manusia telah bergaul dengan manusia yang lainnya yang disebut dengan masyarakat, yang mana oleh Cicero dikatakan ubi societas ibi ius yang artinya bahwa dimana adanya masyarakat disitu pula hukum ada. Sehingga hukum terbentuk oleh manusia untuk dapat mengendalikan setiap pergerakan di antara manusia tersebut.Menjadi sifat pembawaan sebagai manusia dinyatakan bahwa: "Manusia hanya dapat bertahan dalam hidup di dalam komunitas masyarakat sebagaimana manusia terkenal sebagai zoon politicon atau makhluk sosial". ${ }^{1}$

Moch. Isnaeni berpendapat sebagai berikut bahwa: Manusia sebagai satu anggota masyarakat yang memiliki tujuan hidup yang tetap selalu mempertahankan kehidupannya dengan cara tumbuh dan berkembang. Tujuan kehidupan manusia untuk bertumbuh dan berkembang tersebut dimaksud sebagai suatu upaya untuk mendapatkan kemakmuran dan kehidupan yang nyaman. Kehidupan yang makmur dan sejahtera akan dapat dicapai oleh setiap manusia dengan cara melakukan usaha dalam pemenuhan kebutuhan hidup sehari-hari. Kebutuhan hidup sehari-hari setiap manusia itu meliputi antara lain kebutuhan lahir ataupun kebutuhan batin, berarti bahwa manusia dikatakan sejahtera manakala telah terpenuhinya berbagai kebutuhan lahir maupun kebutuhan batin. Terpenuhi Kebutuhan lahir manusia didapat dengan memperoleh asupan-asupan berupa pangan, sandang dan papan beserta siraman keimanan guna mendapatkan ketentraman kehidupannya sebagai bentuk pemenuhan kebutuhan batiniahnya. Sebagai makhluk yang selalu hidup berkelompok dalam suatu gugus manusia juga disebut anggota masyarakat, pasti membutuhkan benda. Tiada suatu kegiatan sehari-hari yang selalu dilakukan manusia sebagai anggota kelompok tanpa dilibatkan benda selaku pendukungnya. Setiap anggota masyarakat yang malang melintang mengejar dipemenuhinya kebutuhan, justru sering berburu benda untuk dimiliki agar kesejahteraannya semakin meningkat. ${ }^{2}$

\footnotetext{
${ }^{1}$ Sudikno Mertokusumo. (1991). Mengenal Hukum (Suatu Pengantar). Yogyakarta: Liberty, h. 3.

${ }^{2}$ H. Moch. Isnaeni. (2016). Pengantar Hukum Jaminan Kebendaan. Surabaya: Revka Petra Media, h. 1-2.
}

Bidang dunia usaha dan perusahaan pasti didalamnya banyak terjadi hubungan hukum, artinya suatu hubungan antar subyek hukum, yang berakibat dari hubungan tersebut diatur oleh hukum. Bidang dunia usaha, termasuk di dalamnya dunia perbankan terdapat hubungan hukum karena suatu perjanjian. Perjanjian merupakan hubungan hukum diantara 2 (dua) pihak/orang atau lebih, yang mana para pihak secara sengaja mengikatkan diri/ saling mengikatkan diri, dengan mana pihak satu mempunyai hak (kreditor), sedangkan pihak lainnya dibebani kewajiban (Pasal 1313 Burgerlijk Wetboek selanjutnya disebut BW, diterjemahkan oleh Subekti dan Tjitrosudibio sebagai Kitab Undang-Undang Hukum Perdata (selanjutnya disebut KUHPerdata).

Di dalam perjanjian, masing-masing terdapat suatu kewajiban yang disebut prestasi, yang isinya sebagai berikut: a. memberi sesuatu (contoh: uang, barang, dsb), b. berbuat sesuatu (contoh: mendirikan bangunan, pengiriman barang, pengangkutan orang, dsb), c. tidak berbuat sesuatu (misal: jalan tidak ditutup, dan lain-lain).

Syarat sahnya suatu perjanjian telah ditetapkan di dalam Pasal 1320 KUHPerdata, yaitu sebagai berikut: a. Sepakat para pihak; b. Kecakapan pihakpihak yang merumuskan perjanjian; c. Objek harus ditentukan/tertentu; d. Sesuatu yang diperjanjikan sejalan dengan undang-undang/halal.

Undang-undang menentukan bahwa perjanjian/ persetujuan yang dibuat secara sah berlaku sebagai undang-undang (mengikat) bagi mereka yang membuatnya. Artinya persetujuan tersebut tidak dapat ditarik kembali atau dibatalkan secara sepihak, kecuali ada kesepakatan kedua belah pihak atau karena alasan-alasan yang oleh undang-undang dinyatakan cukup untuk itu, dan persetujuan tersebut harus dilaksanakan dengan itikad baik.

Pemenuhan kebutuhan lahir yang berupa kesejahteraan dan kemakmuran, untuk mendukungnya diperlukan sarana atau alat berupa kebendaan. Benda merupakan sesuatu yang dimiliki oleh seseorang, jadi segala sesuatu yang tidak dapat dimiliki bukan termasuk dalam pengertian benda. Mengenai pengertian benda ini sangat luas, menurut undangundang benda (zaak) ialah segala sesuatu yang dapat dijadikan objek hak milik. Pasal 499 KUH Perdata dinyatakan bahwa: "Menurut paham undang-undang 
yang dinamakan kebendaan ialah, tiap-tiap barang dan tiap-tiap hak, yang dapat dikuasai oleh hak milik". ${ }^{3}$ Disini benda berarti objek sebagai lawan dari subjek atau orang dalam hukum. Dalam KUHPerdata pengertian benda (zaak) sebagai objek hukum tidak hanya berupa benda yang berwujud, yang dapat ditangkap oleh pancaindera, melainkan juga benda yang tidak berwujud. Benda yang dibutuhkan untuk menunjang manusia menjadi sejahtera meliputi baik bergerak dan benda tidak bergerak, termasuk didalamnya benda yang digunakan untuk usaha.

Benda yang dijadikan sarana untuk menuju sejahteranya manusia sebagai anggota masyarakat tersebut, benda tersebut sebagai hak miliknya akan dipertahankan sesuai dengan tujuannya. Hal ini digunakan untuk lebih meningkatkan kesejahteraan, supaya kelangsungan hidup manusia dalam bermasyarakat bisa berlangsung secara berkelanjutan dari generasi ke generasi.

Peningkatan kesejahteraan manusia dalam memenuhi kebutuhan dan kelangsungan hidupnya bisa dicapai dengan selalu meningkatkan kegiatannya seiring dengan bertambahnya kebendaan yang menjadi miliknya. Pemenuhan kesejahteraan diimbangi dengan semakin bertambahnya kebendaan dilakukan dengan usaha peningkatan usaha yang dikelolanya. Setiap usaha yang dikelola dengan baik akan meningkatkan kemampuan yang mendorong kemajuan untuk menambah benda yang dimiliki manusia supaya tidak statis tetapi selalu dinamis. Usaha manusia untuk menambah kebendaan diikuti dengan usaha yang dijalankan yaitu berupa produktifitas untuk menghasilkan sesuatu. Salah satu usaha memajukan usaha diperlukan dan dibutuhkan dana yang besar. Menjalankan usaha tanpa adanya dukungan dana yang besar tidak dapat terwujud. Perolehan dana untuk memajukan usaha tidak bisa dipenuhi sendiri, sehingga perlu bantuan permodalan dari pihak lain. Adapun cara memperoleh dana dengan bantuan pihak lain dengan melakukan peminjaman.

Para pengusaha dapat mengembangkan usaha atau bisnisnya menjadi besar dan lebih besar serta kuat, sering memerlukan dana pinjaman. Dana pinjaman untuk memperbesar modal usaha dan untuk

${ }^{3}$ R. Subekti dan R. Tjitrosudibio. (1983). Bergerlijk Wetboek (Kitab Undang-Undang Hukum Perdata/Terjemahan). Jakarta: Pradnya Paramita. menjadi kemajuan dalam dunia usaha perusahaannya, umumnya diperoleh dengan jalan mengajukan permohonan kredit kepada bank. Perkreditan merupakan lembaga yang memberikan dukungan dan dorongan kepada ekonomi lemah dan para pengusaha dalam mengembangkan usahanya. Bagi perbankan. Setiap kredit yang disalurkan kepada pengusaha selalu mengandung risiko. Oleh karena itu perlu adanya unsur pengaman yang merupakan salah satu prinsip dasar dalam pemberian kredit/pinjaman di samping unsur keseimbangan dan keuntungan.

Bentuk pengamanan kredit dalam praktek perbankan dilakukan dengan pengikat jaminan. Salah satu jenis pengikat jaminan kebendaan yang dikenal dalam hukum positif adalah jaminan fidusia, sebagai lembaga jaminan atas benda bergerak, jaminan fidusia banyak dipergunakan oleh masyarakat bisnis. Pada awalnya fidusia didasarkan pada yurisprudensi sekarang fidusia sudah diatur dalam undang-undang tersendiri.

Hubungan hukum dalam fidusia terjadi antara debitor (pemberi fidusia) dan kreditor (penerima fidusia) merupakan hubungan hukum yang berdasarkan kepercayaan. Pemberi fidusia percaya bahwa penerima fidusia mau mengembalikan hak milik barang yang telah diserahkan, setelah dilunasi hutangnya. Sebaliknya penerima fidusia percaya bahwa pemberi fidusia tidak akan menyalahgunakan barang jaminan yang berada dalam kekuasaannya.

Fidusia sebagai salah satu lembaga jaminan kebendaan, oleh lembaga legislatif sudah dituangkan dalam bentuk Undang-Undang Republik Indonesia Nomor 42 Tahun 1999 tentang Jaminan Fidusia. Salah satu keistimewaan lembaga jaminan kebendaan adalah bahwa objek fidusia sebagai agunan masih tetap dikuasai oleh debitor supaya tetap dapat melanjutkan usahanya, dengan harapan hasil usahanya tersebut dapat dipergunakan untuk melunasi utangnya kepada kreditor. Hanya saja UUJF banyak mengundang permasalahan akibat antara pasal yang satu dengan pasal yang lain sering tidak harmonis bahkan tidak jelas atau terdapat konflik norma. Ketidakjelasan itu antara lain tentang kedudukan debitor saat menguasai objek jaminan fidusia, kedudukan hukum debitor sebagai pemilik atau sebagai menguasai objek jaminan fidusia, ternyata UUJF membisu seribu bahasa dan 
tidak pernah memberikan penjelasan atau adanya kekosongan norma.

\section{PERUMUSAN MASALAH}

Berkaitan dengan latar belakang tersebut maka permasalahan yang akan dijadikan isu hukum dalam penelitian ini adalah: Bagaimana karakteristik perlindungan hukum debitor dalam menguasai objek jaminan fidusia; dan Bagaimana kedudukan hukum debitor dalam menguasai objek jaminan fidusia.

\section{PEMBAHASAN}

\section{Perjanjian kredit Jaminan Fidusia}

Perjanjian kredit, yang di dalam praktik sering disebut akad kredit, sebenarnya di dalam bidang hukum perdata disebut perjanjian pinjam-meminjam atau hutang-piutang. Pasal 1754 KUHPerdata menyebutkan bahwa: pinjam meminjam ialah persetujuan dengan mana pihak yang satu memberikan kepada pihak yang lain suatu jumlah tertentu barangbarang yang menghabis karena pemakaian, dengan syarat bahwa pihak yang belakangan ini akan mengembalikan sejumlah yang sama dari macam dan keadaan yang sama pula. Pasal tersebut dapat dimaknai sebagai suatu perjanjian yang satu pihak (kreditor) berjanji untuk menyediakan barang yang habis karena pemakaian, sedangkan pihak lain (debitor) berjanji untuk mengembalikan barang tersebut dengan barang lain dengan jenis, mutu, dan jumlah yang sama di lain waktu, baik disertai dengan disertai bunga atau tidak sesuai kesepakatan.

Menurut Mariam Darus Badrulzaman menyatakan bahwa: Perjanjian kredit perbankan di Indonesia mempunyai arti yang khusus dalam rangka pembangunan, tidak merupakan perjanjian pinjam-meminjam uang yang biasa. Perjanjian kredit menyangkut kepentingan nasional. ${ }^{4}$ Selanjutnya secara etimologi istilah kredit berasal dari bahasa Latin "credere", yang berarti kepercayaan. Hal ini menunjukkan, bahwa yang menjadi dasar pemberian kredit oleh bank kepada nasabah debitor adalah kepercayaan. Menurut Kamus Besar Bahasa Indonesia, salah satu pengertian kredit adalah pinjaman uang dengan pembayaran pengembalian secara mengangsur atau pinjaman sampai batas

${ }^{4}$ Mariam Darus Badrulzaman. (1994). Aneka Hukum Bisnis. Bandung: Alumni, h. 105. jumlah tertentu yang diijinkan oleh bank atau badan lain. $^{5}$

Pemimjaman dana bisa dengan pihak perseorangan dan bisa dengan pihak atau lembaga keuangan. Peminjaman dana dengan pihak perseorangan caranya memang sederhana dan proses yang cepat, praktis dan singkat tanpa jaminan/ agunan kebendaan dengan risiko yang besar yaitu pengenaan bunga yang tinggi sekali di luar batas yang wajar dan tanpa perlindungan hukum yang memadai. Peminjaman dana dengan pihak lembaga keuangan mempunyai jaminan perlindungan hukum yang pasti artinya ada jaminan kepastian hukum diantara kedua pihak. Jaminan perlindungan hukum ini memudahkan para pihak yang membutuhkan dana, guna kelangsungan usaha semakin aman dan sesuai dengan kehendak para pihak untuk melakukan peminjaman uang.

Lembaga keuangan ada 2 jenisnya yaitu lembaga keuangan bukan bank dan lembaga keuangan bank. Pada dasarnya lembaga keuangan adalah sebagai perantara dari pihak yang kelebihan dana (surplus of funds) dengan pihak yang kekurangan dana (lack of funds), sehingga peranan dari lembaga keuangan yang sebenarnya adalah sebagai perantara keuangan masyarakat (financial intermediary). Lembaga keuangan bukan bank adalah suatu badan yang melakukan kegiatan di bidang keuangan berupa usaha menghimpun dana, memberikan kredit, sebagai perantara dalam usaha mendapatkan sumber pembiayaan, dan usaha penyertaan modal, semuanya itu dilakukan secara langsung, atau tidak langsung melalui penghimpunan dana terutama dengan jalan mengeluarkan kertas berharga, dengan demikian lembaga keuangan bukan bank beroperasi lebih banyak di pasar uang dan modal. ${ }^{6}$

Lembaga keuangan bank, sebagai salah satu lembaga keuangan yang paling penting peranannya dalam masyarakat. Dalam menjalankan peranannya maka bank bertindak sebagai salah satu bentuk lembaga keuangan yang bertujuan memberikan kredit, dan jasa-jasa keuangan lainnya. "Adapun pemberian kredit itu dilakukan baik dengan modal sendiri, atau dengan dana-dana yang dipercayakan oleh pihak

\footnotetext{
5 Hermansyah. (2005). Hukum Perbankan Nasional Indonesia. Jakarta: Prenada Media, h. 55.

${ }^{6}$ Muhamad Djumhana. (1996). Hukum Perbankan di Indonesia. Bandung: Citra Aditya Bakti, h. 63-64.
} 
ketiga maupun dengan jalan memperedarkan alatalat pembayaran baru berupa uang giral". ${ }^{7}$

Lembaga keuangan bank meliputi: Bank Umum, dan Bank Perkreditan Rakyat. UndangUndang Nomor 10 Tahun 1998 tentang Perubahan atas Undang-Undang Nomor 7 Tahun 1992 tentang Perbankan (selanjutnya disebut UU Perbankan), Pasal 1 angka 2 menyatakan bahwa "Bank adalah badan usaha yang menghimpun dana dari masyarakat dalam bentuk simpanan dan menyalurkannya kepada masyarakat dalam bentuk kredit dan atau bentukbentuk lainnya dalam rangka meningkatkan taraf hidup rakyat banyak".

Bank adalah salah satu lembaga keuangan yang berperan penting dalam perekonomian di Indonesia. Menurut UU Perbankan, bank merupakan lembaga perantara keuangan, dimana bank bertugas untuk menghimpun dana dari masyarakat dalam bentuk kredit dan atau bentuk-bentuk lainnya dalam rangka meningkatkan taraf hidup orang banyak.

Pengertian di paragraf sebelumnya dapat dinyatakan bahwa peran bank adalah suatu lembaga yang berperan sebagai perantara keuangan (financial intermediary) antara pihak-pihak yang memiliki kelebihan dana (surplus of funds) dengan pihak-pihak yang memerlukan dana (deficit of funds). Perbankan di Indonesia berfungsi sebagai penghimpun dan penyalur dana masyarakat, serta bertujuan untuk menunjang pelaksanaan pembangunan nasional dalam rangka meningkatkan pemerataan pembangunan dan hasil-hasilnya, pertumbuhan ekonomi dan stabilitas nasional, ke arah peningkatan taraf hidup rakyat banyak. Perbankan memiliki kedudukan yang strategis, yakni sebagai penunjang kelancaran sistem pembayaran, pelaksanaan kebijakan moneter dan pencapaian stabilitas sistem keuangan, sehingga diperlukan perbankan yang sehat, transparan dan dapat dipertanggungjawabkan.

Bank sebagai salah satu lembaga keuangan mempunyai fungsi sebagaimana tertuang dalam UU Perbankan. Pasal 3 UU Perbankan menyatakan bahwa "Fungsi utama perbankan Indonesia adalah sebagai penghimpun dan penyalur dana masyarakat." Kegiatan menyalurkan dana yang dilakukan oleh Bank sebagai lembaga intermediasi adalah kegiatan memberikan kredit kepada masyarakat dalam rangka

${ }^{7}$ OP. Simorangkir. (1989). Kamus Perbankan. Jakarta: Bina Aksara, h. 33. meningkatkan taraf hidup rakyat, seperti yang tertera dalam UU Perbankan yang menyatakan Kredit adalah: penyediaan uang atau tagihan yang dapat dipersamakan dengan itu, berdasarkan persetujuan atau kesepakatan pinjam meminjam antara bank dengan pihak lain yang mewajibkan pihak peminjam untuk melunasi utangnya setelah jangka waktu tertentu dengan pemberian bunga.

Bank sebagai lembaga intermediary yaitu sebagai penghubung untuk menyalurkan kredit kepada para nasabahnya selalu menggunakan prinsip-prinsip umum perbankan yaitu prinsip kepercayaan dan kehati-hatian. Penegakan prinsip kepercayaan bank diwujudkan dengan mengajukan kriteria dalam menganalisa kredit yang akan diberikan kepada debitor yaitu: Penerapan asas 5C, meliputi: 1. Character (sifat-sifat calon debitor), 2. Capital (modal dasar calon debitor), 3. Capacity (kemampuan calon debitor), 4. Collateral (jaminan yang disediakan/tersedia oleh calon debitor), 5 . Condition of economy (kondisi perekonomian calon debitor). ${ }^{8}$ Selain itu juga ditentukan dengan aspek personality, purpose, prospect, payment. Prinsip kehati-hatian ditegakkan dalam penyaluran dana kepada masyarakat dalam bentuk kredit supaya aman yaitu dengan agunan atau jaminan.

Menurut Etty Mulyati, dinyatakan bahwa: Pemberian kredit dalam praktiknya bank wajib melakukan perhatian dan penilaian dari berbagai aspek yaitu dengan menggunakan prinsip kehatihatian yang dikenal dengan prudential banking principles yang lebih dikenal adalah prinsip 6C, yang berkaitan dengan penjabaran Pasal 8 UU Perbankan, yaitu: 1. Character (watak debitor), watak adalah pribadi yang baik dari calon debitor, yaitu mereka yang selalu menepati janjinya dan berupaya mencegah perbuatan tercela; 2. Capacity (kemampuan calon debitor), dalam mengelola usahanya harus diketahui secara pasti oleh pihak bank dari kemampuan manajemennya dan sumber daya manusianya, mampu berproduksi dengan baik yang dapat dilihat dari kapasitas produksinya; 3 . Capital (modal), untuk memperoleh kredit calon debitor harus memiliki modal terlebih dahulu, jumlah, dan struktur modal calon debitor harus dapat diteliti dan diketahui tingkat rasio dan solvabilitasnya; 4. Collateral (jaminan), jaminan

${ }^{8}$ Muhamad Djumhana. op.cit., h. 230. 
sebagai sarana pengaman atas risiko yang mungkin timbul atas cidera janjinya nasabah di kemudian hari; 5. Condition of economi (kondisi ekonomi), kondisi ekonomi secara umum sarat perhatian dari sektor usaha di pemohon kredit perlu mendapatkan perhatian dari pihak bank umum memperkecil risiko yang mungkin timbul akibat kondisi ekonomi. Kondisi tersebut terpengaruh oleh keadaan sosial, politik dan ekonomi dari suatu periode tertentu dan perkiraan yang akan terjadi pada waktu mendatang; 6. Constraints (keadaan yang menghambat), sebelum memberikan pembiayaan juga memperhatikan faktor hambatan atau rintangan yang ada pada suatu daerah atau wilayah tertentu yang menyebabkan suatu proyek tidak dapat dilaksanakan. ${ }^{9}$

Selanjutnya dalam menentukan unsur pemberian pinjaman kepada debitor, selain asas $5 \mathrm{C}$ dan asas $6 \mathrm{C}$ terdapat juga prinsip 7P yang berisi sebagai berikut: 1. Personality yaitu menilai dari segi kepribadiannya atau tingkah lakunya sehari-hari maupun masa lalunya; 2. Party yaitu mengklasifikasikan nasabah ke dalam klasifiasi tertentu atau golongan-golongan tertentu berdasarkan modal, loyalitas serta karakternya; 3. Purpose yaitu untuk mengetahui tujuan nasabah dalam mengambil kredit, termasuk jenis yang diinginkan nasabah; 4. Prospect yaitu untuk menilai usaha nasabah di masa yang akan datang apakah menguntungkan atau tidak, atau dengan kata lain mempunyai prospek atau sebaliknya; 5. Payment merupakan ukuran bagaimana cara nasabah mengembalikan kredit yang telah diambil atau dari sumber mana saja untuk pengembalian kredit yang diperolehnya; 6. Profitability untuk menganalisis bagaimana kemampuan nasabah dalam mencari laba; 7. Protection tujuannya adalah bagaimana menjaga kredit yang dikucurkan oleh bank namun melalui suatu perlindungan. ${ }^{10}$

Berdasarkan penerapan asas $5 \mathrm{C}$ dan asas $6 \mathrm{C}$ sebagaimana disebut dalam paragraf sebelumnya unsur collateral (jaminan yang disediakan/ tersedia oleh debitor) menjadi penting bagi bank saat menyalurkan dana pinjaman kepada calon debitornya. Prinsip 7P dalam hal mengukur nasabah

\footnotetext{
${ }^{9}$ Etty Mulyati. (2016). Kredit Perbankan Aspek Hukum dan Pengembangan Usaha Mikro Kecil dalam Pembangunan Perekonomian Indonesia. Bandung: Refika Aditama, h. 83-84.

10 http://blog.stie-mce.ac.id/tita/2014/08/31/prinsipprinsip-penilaian-kredit-6c-7p-3-r-apa-sih-isinya/, diunduh tanggal 31 juli 2017.
}

dari berbagai aspek, baik aspek pertanggungjawaban nasabah dalam pengembalian kreditnya maupun kemampuan nasabah dalam menggunakan kreditnya untuk mendapatkan keuntungan/laba, sehingga pihak pemberi pinjaman merasa yakin nasabahnya dapat melunasi kreditnya tepat waktu.

Lembaga keuangan bukan bank adalah suatu badan yang melakukan kegiatan di bidang keuangan berupa usaha menghimpun dana, memberikan kredit sebagai perantara dalam usaha mendapatkan sumber pembiayaan, dan usaha penyertaan modal, semuanya itu dilakukan secara langsung, atau tidak langsung melalui penghimpunan dana terutama dengan jalan mengeluarkan kertas berharga, dengan demikian lembaga ini lebih banyak beroperasi di pasar uang dan pasar modal. ${ }^{11}$

Dalam rangka pembangunan ekonomi Indonesia, khususnya bidang hukum yang minta perhatian serius dalam pembinaan diantaranya adalah bidang hukum jaminan. ${ }^{12}$ Kenyataan saat ini pesat sekali perkembangan dan pertumbuhan ekonomi yang selalu diikuti dengan masyarakat dalam memenuhi kebutuhan hidup sehari-hari. Selanjutnya Mariam Darus Badrulzaman, menyatakan bahwa: "Jaminan adalah suatu tanggungan yang diberikan seorang debitor dan atau pihak ketiga kepada kreditor untuk menjamin kewajibannya dalam suatu perikatan". ${ }^{13}$

Perekonomian bangsa Indonesia yang ingin dibangun hendaknya bertumpu pada penyelenggaraan yang berkeadilan sosial dan perikemanusiaan, di mana golongan-golongan pelaku ekonomi dalam melaksanakan usahanya tidak semata mengejar kepentingan keuntungan, oleh karena itu proses produksi, distribusi, dan konsumsi barang dan jasa perlu tumbuh secara seimbang, serasi, dan bersama atau bermitra, serta saling mengisi dan saling menunjang sehingga masing-masing ataupun secara bersama dapat berkembang menjadi kekuatan yang tangguh. Komitmen meningkatkan peran rakyat dalam perekonomian sangat diperlukan, agar ekonomi rakyat dalam bentuk usaha kecil dan masih lemah serta kurang tangguh untuk menghadapi dan

\footnotetext{
${ }^{11}$ Muhamad Djumhana. loc.cit.

${ }^{12}$ Sri Soedewi Masjchoen Sofwan. (1980). Hukum Jaminan di Indonesia Pokok-Pokok Hukum Jaminan dan Jaminan Perorangan. Yogyakarta: Bina Usaha, h. 1.

13 Mariam Darus Badrulzaman. (2000). Beberapa Permasalahan Hak Jaminan. Jakarta: Yayasan Pengembangan Bisnis, h. 12.
} 
memperoleh manfaat dari ekonomi terbuka menjadi mantap, berkembang dan mandiri. Pemberdayaan lembaga jaminan fidusia sangat ideal bagi usaha kecil.

Konstruksi jaminan fidusia didasarkan kepercayaan mempunyai kelebihan karena objek yang dijadikan jaminan dikuasai oleh debitor guna menjalankan usahanya. Benda yang dibebani dengan jaminan fidusia wajib didaftarkan. Pendaftaran dilakukan pada Kantor Pendaftaran Fidusia. Pendaftaran ini dapat memperkuat keberhasilan permohonan suatu kredit yang diajukan kepada bank oleh pengusaha kecil, sebab dengan didaftarkan berarti lebih menjamin kepentingan pihak yang menerima fidusia (kreditor). Pendaftaran jaminan fidusia memberikan kepastian hukum kepada para pihak yang berkepentingan dan pendaftaran jaminan fidusia memberikan hak yang didahulukan kepada penerima fidusia dari pada kreditor lain.

Calon nasabah untuk mendapatkan kredit, yang tujuannya adalah untuk mengembangkan dan memperbesar usaha, kalau yang disodorkan atau diserahkan benda sebagai alat utama usaha maka bentuk jaminan gadai tidak bisa terlaksana, kemudian dipilihlah jaminan fidusia. Tidak ubahnya dengan kegiatan pinjam meminjam yang telah kita ketahui sudah lama dilakukan oleh masyarakat Indonesia. Dalam pelaksanaannya biasanya dipersyaratkan bahwa adanya penyerahan jaminan hutang kepada pihak pemberi hutang oleh peminjam. Jaminan bisa berupa uang atau benda atau juga bisa berupa janji penangguhan hutang sehingga merupakan jaminan perorangan.

Dari sudut pandang ekonomi, pertukaran seyogyanya dilakukan atas dasar sukarela yang saling mengoptimalkan daya guna sumber untuk mencapai peningkatan keuntungan. Atas dasar sukarela ini, para pihak memiliki rasa saling ketergantungan yang tinggi, sehingga diharapkan mampu berjalan independent tanpa permasalahan hukum.

Keberadaan kontrak dalam hal ini untuk memfasilitasi proses pertukaran hak dan kewajiban secara sukarela tersebut. Pada saat pertukaran ini tidak sesuai dengan hal-hal yang ditentukan dalam kontrak, terutama menyangkut hal-hal di masa akan datang, proses yang awalnya sukarela ini dimanfaatkan untuk mendapatkan keuntungan oleh pihak yang merasa diuntungkan. ${ }^{14}$

Pelaksanaan penjaminan yang juga harus diperhatikan oleh para pelaku adalah harus sesuai dengan hukum atau peraturan yang telah ditentukan. Hukum jaminan yang merupakan ketentuan yang mengatur dengan penjaminan dalam rangka hutang piutang yang dapat terbagi dalam berbagai bentuk yang telah berlaku saat ini.

Menurut UU Perbankan dikatakan bahwa: "Kredit adalah penyediaan uang atau tagihan-tagihan yang dapat disamakan dengan itu berdasarkan persetujuan pinjam meminjam antara bank dengan pihak lain dalam hal dimana pihak peminjam berkewajiban melunasi hutangnya setelah jangka waktu yang ditentukan dengan sejumlah bunga yang disepakati”.

Mariam Badrulzaman menyatakan bahwa: Membedakan pengertian tersebut ke dalam 2 (dua) hal, yaitu: 1. Perjanjian kredit sebagai perjanjian pendahuluan, Artinya bahwa, perjanjian kredit adalah "perjanjian pendahuluan" dari penyerahan uang. Perjanjian pendahuluan ini merupakan hasil pemufakatan antar pemberi dan penerima perjanjian mengenai hubungan hukum antara keduanya. Perjanjian tersebut bersifat konsensual obligator (perjanjian yang timbul atau terbentuk, bersifat mengikat); 2. Perjanjian kredit merupakan perjanjian pendahuluan (pactum de contrafendo). Maksudnya adalah perjanjian ini mendahului perjanjian hutangpiutang (pinjam-meminjam). Sedangkan perjanjian hutang-piutang merupakan pelaksanaan dari perjanjian pendahuluan atau perjanjian kredit. ${ }^{15}$

Menurut Munif Fuady menyatakan bahwa: "Lembaga Jaminan kebendaan untuk menopang perjanjian kredit dapat berupa gadai, hipotek hak tanggungan, dan fidusia". ${ }^{16}$

Fidusia Lembaga jaminan Fidusia diatur dengan Undang-undang Nomor 42 Tahun 1999 tentang Jaminan Fidusia (selanjutnya disebut UUJF). Fidusia adalah penyerahan hak milik berdasarkan kepercayaan atas barang bergerak, dengan tetap

\footnotetext{
${ }^{14}$ Fajar Sugianto. (2014). Buku Hukum Economic Analysis of Law Seri Analisis Keekonomian tentang Hukum. Jakarta: Kencana Prenadamedia Grup, h. 80.

${ }^{15}$ Budi Untung. (2000). Kredit Perbankan di Indonesia. Yogyakarta: Penerbit Andi, h. 30.

${ }^{16}$ Munir Fuady. (1996). Hukum Perkreditan Kontempore. (Cetakan Kesatu). Bandung: Citra Aditya Bakti, h. 65.
} 
menguasai barang-barang tersebut. Pasal 1 angka 1 undang-undang tersebut memberikan pengertian "Fidusia sebagai pengalihan hak kepemilikan suatu benda atas dasar kepercayaan dengan ketentuan bahwa benda yang hak kepemilikannya dialihkan tersebut tetap dalam penguasaan benda pemilik benda." Objek jaminan Fidusia berupa benda bergerak yang tidak dapat dibebani Hak Tanggungan atau Hipotek, utang yang ada, utang yang akan ada dan utang yang pada saat eksekusi dapat ditetapkan (Pasal 3 dan 7 UUJF). Sifat Jaminan Fidusia adalah accessoir dan bersifat kebendaan.

Hukum jaminan memiliki kaitan yang erat dengan bidang hukum benda dan perbankan. Bidang hukum perbankan disangkut pautkan dengan jaminan terletak pada fungsi penbankan yaitu penghimpun dan penyalur dana bagi masyarakat, salah satu usahanya adalah memberikan kredit. Kredit merupakan faktor pendukung bagi pembangunan ekonomi. Hal ini berarti perkreditan mempunyai arti penting dalam berbagai aspek pembangunan seperti perdagangan perindustrian transportasi dan sebagainya. ${ }^{17}$

Dari sudut teoritik atau konseptual bahwa pembaharuan Sistem Hukum Jaminan Fidusia Nasional merupakan rangkaian kesatuan sub-sistem Hukum Nasional Jaminan Fidusia ke dalam substansi Hukum jaminan fidusia, struktur hukum jaminan fidusia, dan budaya hukum jaminan fidusia. Sistem Hukum Nasional yang akan dibangun diperlukan landasan nilai-nilai atau ide sebagai pedoman yang sesuai dengan pandangan hidup maupun ideologi bangsa Indonesia sehingga ilmu hukum tersebut bisa berlaku secara nasional. Dari sudut teoritik/ konseptual bahwa pembaharuan Sistem Hukum Jaminan Fidusia Nasional merupakan rangkaian kesatuan sub-sistem Hukum Nasional Jaminan Fidusia ke dalam substansi Hukum jaminan fidusia, struktur hukum jaminan fidusia, dan budaya hukum jaminan fidusia. Sistem Hukum Nasional yang akan dibangun diperlukan landasan nilai-nilai/ide sebagai pedoman yang sesuai dengan pandangan hidup maupun ideologi bangsa Indonesia sehingga ilmu hukum tersebut bisa berlaku secara nasional hukum (dan penegakannya) mengalami pertukaran yang erat dan intensif dengan lingkungan politik dan ekonomi. Apa yang terjadi pada bidang hukum

${ }^{17}$ H.Tan Kamelo. (2004). Hukum Jaminan Fidusia Suatu Kebutuhan Yang Didambakan. Bandung: Alumni, h. 1. merupakan fungsi dari proses yang terjadi di kedua bidang tersebut.

Ada pemikiran bahwa hukum di Indonesia selalu dapat dikembalikan pada hubungan kekuatan politik dan perkembangan masyarakat. Ironisnya, situasi demikian dalam pengembangan ilmu hukum di Indonesia tidak bergeming dan lebih didominasi paradigma positivisme. Paradigma itu sangat mendominasi bahkan mentradisi dalam pemikiranpemikiran hukum di Indonesia. ${ }^{18}$ Selanjutnya lembaga fidusia dikenal dengan berbagai nama atau istilah. Pada zaman Romawi lembaga ini dikenal dengan istilah Fiducia-cum Creditore. Selain itu Asser van Oven juga menyebutkan dengan istilah Hak Milik Sebagai Jaminan (Bezitloos Zekerheidsrecht), Kahrel menggunakan istilah Gadai yang diperluas (Verruimd Pandbegrip). Sedangkan menurut Dr. A. Veenhoven menyebut dengan istilah Penyerahan Hak Milik Sebagai Jaminan (Eigendomsoverdracht tot Zekerheid). Tetapi pada akhirnya masyarakat lebih menggunakan dengan istilah yang singkat, yaitu fidusia karena lebih pendek dan lebih mudah penyebutannya. ${ }^{19}$

\section{Karakteristik Jaminan Fidusia}

Fidusia berasal dari kata "Fides" yang berarti kepercayaan. Dapat kita mengerti bahwa gambaran hubungan hukum antara debitor pemberi fidusia dengan kreditor penerima fidusia merupakan suatu hubungan hukum yang didasari kepercayaan, dengan kata lain pihak debitor percaya terhadap pihak kreditor, bahwa kreditor nantinya akan mengembalikan hak milik yang telah diserahkan kepadanya, setelah debitor melunasi seluruh hutangnya. Di sisi lain kreditor juga percaya bahwa debitor tidak akan menyalahgunakan barang yang dijadikan jaminan yang berada di bawah kekuasaannya dan berkenan memelihara benda tersebut secara baik.

Sebenarnya latar belakang lahirnya lembaga fidusia adalah karena adanya kebutuhan dalam praktek. Kebutuhan tersebut didasarkan atas faktafakta sebagai berikut:

${ }^{18}$ Yusriyadi. (2009). Tebaran Pemikiran Kritis Hukum dan Masyarakat. Malang: Surya Pena Gemilang, h. 55.

${ }^{19}$ Andi Hamzah dan Senjun Manullang. (1987). Lembaga Fidusia dan Penerapannya di Indonesia. Cet. Pertama. Jakarta: Ind-Hill Co. 
1. Barang bergerak sebagai jaminan utang.

Sebagaimana diketahui bahwa menurut sistem hukum kita, dan juga hukum di kebanyakan negara-negara Eropa Kontinental, bahwa jika yang menjadi objek jaminan utang adalah benda bergerak, maka jaminannya diikat dalam bentuk gadai. Dalam hal ini, objek gadai tersebut harus diserahkan kepada pihak yang menerima gadai (kreditor). Sebaliknya, jika yang menjadi objek jaminan utang adalah benda bergerak, maka jaminan tersebut haruslah berbentuk hipotek (sekarang ada hak tanggungan). Dalam hal ini, objek jaminan tidak diserahkan kepada kreditor, tetapi tetap dalam kekuasaan debitor. Akan tetapi, terdapat kasus-kasus dimana barang objek jaminan utang masih tergolong barang bergerak, tetapi pihak debitor enggan menyerahkan kekuasaan atas barang tersebut kepada kreditor, sementara pihak kreditor tidak mempunyai kepentingan bahkan kerepotan jika barang tersebut diserahkan kepadanya. Karena itu, dibutuhkanlah adanya suatu bentuk jaminan utang yang objeknya masih tergolong benda bergerak tetapi tanpa menyerahkan kekuasaan atas benda tersebut kepada pihak kreditor. Akhirnya, munculah bentuk jaminan baru dimana objeknya benda bergerak, tetapi kekuasaan atas benda tersebut tidak beralih dari debitor kepada kreditor. Inilah yang disebut dengan jaminan fidusia. Sebaliknya, ada juga kasus-kasus dimana jaminan utang diberikan atas benda tidak bergerak, tetapi ada kebutuhan atau atau para pihak sepakat agar barang tidak bergerak tersebut dialihkan kekuasaannya kepada pihak kreditor. Inilah yang mendorong munculnya "gadai tanah" yang banyak dipraktekkan dalam sistem hukum adat.

2. Barang objek jaminan utang yang bersifat khusus.

Adanya barang-barang yang sebenarnya masih termasuk barang bergerak, tetapi mempunyai sifat-sifat seperti barang tidak bergerak. Sehingga pengikatannya dengan gadai dirasa tidak cukup memuaskan, terutama karena adanya kewajiban menyerahkan kekuasaan dari benda objek jaminan utang tersebut. Karena itu jaminan fidusia, jaminan fidusia menjadi pilihan. Misalnya, fidusia atas pesawat terbang dahulu sebelum berlakunya Undang-Undang tentang Penerbangan No. 15 Tahun 1992. Dengan undang-undang tersebut, hipotek dapat diikatkan atas sebuah pesawat terbang. Atau terhadap hasil panen, yang juga tidak mungkin diikatkan dengan hipotek.

3. Perkembangan pranata hukum kepemilikan yang baru.

Perkembangan kepemilikan atas bendabenda tertentu juga tidak selamanya dapat diikuti oleh perkembangan hukum jaminan, sehingga ada hak-hak barang yang sebenarnya tidak bergerak, tetap tidak dapat diikatkan dengan hipotek. Misalnya, tidak dapat diikatkan dengan hipotek atas strata title atau atas rumah susun. Maka Undang-Undang tentang Rumah Susun No. 16 tahun 1985, memperkenalkan fidusia terhadap hak atas satuan rumah susun tersebut. Akan tetapi, sekarang dengan berlakunya Undang-Undang Hak Tanggungan No. 4 Tahun 1996, maka strata title dapat diikatkan hak tanggungan asalkan memenuhi syarat-syarat tertentu.

4. Barang bergerak objek jaminan utang tidak dapat diserahkan.

Adakalanya pihak kreditor dan pihak debitor sama-sama tidak berkeberatan agar diikatkan jaminan utang berupa gadai atas utang yang dibuatnya, tetapi barang yang dijaminkan karena sesuatu dan lain hal tidak dapat diserahkan kepemilikannya kepada pihak kreditor. Misalnya, saham perseroan yang belum dicetak sertifikatnya. Karena itu, timbul fidusia saham. Atau fidusia atas benda bergerak, tetapi benda tersebut karena sesuatu dan lain hal masih ditangan pihak ketiga, sehingga penyerahan barang tersebut belum dapat dilakukan. Karena itu, gadai tidak dapat dilakukan. ${ }^{20}$

Apabila dikaitkan dengan lahirnya UUJF, maka UUJF dapat dianalisa mendasarkan teori Robert B. Seidman sebagai berikut: 1. Rule atau peraturan, peraturan jaminan fidusia dilahirkan untuk dibuat secara jelas dan tidak multitafsir, berdasarkan syarat formal pembentukan UUJF sudah jelas dan tidak multi tafsir, bahkan telah diundangkan dalam berita negara dan tambahan berita negara; 2. Dari

${ }^{20}$ Munir Fuady. (2000). Jaminan Fidusia. Cet. Pertama. Bandung: Citra Aditya Bakti, h. 1-3. 
sisi opportunity atau peluang, karena hakikat fidusia merupakan pemberian kepercayaan penguasaan benda modal sebagai jaminan fidusia di pihak debitor, maka dikhawatirkan adanya peluang untuk mengalihkan benda modal tersebut kepada pihak ketiga atau pihak lain, walaupun ada kewajiban bagi penerima benda jaminan fidusia untuk mendaftarkan sebagai wujud kepastian hukum; 3. Dari sisi capacity atau kemampuan, pendaftaran benda jaminan fidusia tidak akan memberikan peluang kepada debitor untuk mengalihkan benda modal sebagai jaminan fidusia dalam waktu tertentu untuk pelunasan hutangnya, dengan tidak dapatnya debitor mengalihkan benda modal yang dijaminkan fidusia tersebut, membuktikan bahwa debitor mempunyai kemampuan untuk dapat mengembalikan hutang kepada pihak kreditor sesuai dengan waktu yang telah diperjanjikan; 4. Dari sisi communication atau komunikasi, dengan diaturnya jaminan fidusia dalam UUJF, sebagai induk semua pengaturan fidusia, mudah dikenal dan disosialisasikan apabila dibandingkan dengan pengaturan fidusia yang mendasarkan pada Yurisprudensi Mahkamah Agung negara Belanda Hoge Raad yang menghasilkan FEO (fiduciare Eigendom Overdracht); 5. Dari sisi interest atau kepentingan, adanya jaminan fidusia sebagaimana telah dibuat dalam UUJF, akan memberikan manfaat bagi pelaku usaha, khususnya usaha mikro, kecil dan menengah untuk mendapatkan tambahan modal usaha, masyarakat berupa terpenuhinya kebutuhan akan pangan, sandang dan papan serta negara berupa telah dihasilkannya salah satu bentuk hukum nasional berupa unifikasi hukum bidang jaminan fidusia, sebagaimana tertuang dalam konsideran UUJF; 6. Dari sisi process atau proses, pembentukan UUJF melalui berbagai pertimbangan antara lain pertimbangan dari sisi hukum dan di luar hukum. Fidusia yang berasal dari kata fides yang berarti kepercayaan bahwa pemilik benda modal menyerahkan hak kepemilikannya kepada pemberi modal (kreditor). Harapan yang akan dikehendaki oleh kreditor, dengan masih memberikan kepercayaan untuk melepaskan benda jaminan fidusia tetap dikuasai debitor. Seyogyanya debitor juga harus memperlakukan benda modalnya sebagai miliknya sendiri memang secara kenyataanya demikian, walaupun secara yuridis hak kepemilikannya beralih kepada kreditor. Selain itu debitor bertindak atas benda jaminan fidusia ini sebagai bapak rumah yang baik sebagaimana tertuang dalam Pasal 1560 KUH Perdata yang menyatakan bahwa: Si penyewa harus memenuhi dua kewajiban utama, yaitu: Untuk memakai barang yang disewakan sebagai seorang bapak rumah yang baik, sesuai dengan tujuan yang diberikan pada barang itu menurut perjanjian sewanya, atau jika ada sesuatu perjanjian mengenai itu, menurut yang dipersangkakan hubungan dengan keadaan; 7. Dari sisi ideology atau nilai, dalam kenyataannya sejak diundangkannya UUJF hingga sekarang eksistensi peraturan perundangundangan fidusia tidak mengalami hambatan dalam pelaksanaannya, walaupun kalau dicermati dalam pasal-pasal UUJF terdapat ketidakjelasan antara pasal yang satu dengan pasal yang lain, bahkan nilai subtansi UUJF tidak bertentangan dengan falsafah dan nilai-nilai yang ada dalam Pancasila sebagai dasar negara dan sebagai pandangan hidup bangsa Indonesia.

\section{Jaminan Fidusia Sebagai Perjanjian Accessoir dari Perjanjian Pokok}

Keberadaan lembaga jaminan mempunyai tugas untuk memperlancar dan mengamankan pemberian kredit, maka jaminan yang baik (ideal) adalah jaminan yang memenuhi syarat-syarat dapat secara mudah membantu perolehan kredit itu oleh pihak yang memerlukannya; tidak melemahkan potensi (kekuatan) si pencari kredit untuk melakukan (meneruskan) usahanya; memberikan kepastian kepada si pemberi kredit dalam arti bahwa barang jaminan setiap waktu tersedia untuk dieksekusi, yaitu bila perlu dapat mudah diuangkan untuk melunasi utangnya si penerima kredit.

Menurut hukum, semua perjanjian jaminan utang merupakan perjanjian accessoir. Fidusia sebagai lembaga jaminan juga merupakan perjanjian yang sifatnya accessoir di samping adanya perjanjian pokok yaitu perjanjian utang piutang atau perjanjian pinjam uang. Dalam kedudukannya sebagai perjanjian yang bersifat accessoir, lembaga jaminan fidusia ini dapat menimbulkan hak yang zakelijk (hak kebendaan). Seperti halnya dengan hak jaminan yang lainnya, hak eigendom ini melekat atau mengikuti para pihak kreditor. Sehingga juga mempunyai sifat kebendaan dalam arti terhadap pihak ketiga ada hak eigendom, tetapi juga bersifat obligatori dalam arti 
antara para pihak sendiri, si berpiutang bukanlah eigenaar. Dengan demikian disini hanya perjanjian semacam pand..$^{21}$

Uraian di atas menjadi latar belakang pengertian fidusia yang dikemukakan oleh Hamzah dan Senjun Manulang yang dapat dljadikan pegangan sebagai suatu cara pengoperan hak milik dari pemiliknya (debitor), berdasarkan adanya suatu perjanjian pokok (perjanjian hutang piutang) kepada kreditor, akan tetapi yang diserahkan hanya haknya saja secara yuridische levering dan hanya dimiliki oleh kreditor secara kepercayaan saja (sebagai Jaminan hutang debitor) sedangkan, "Barangnya tetap dikuasai oleh debitor tetapi bukan lagi sebagai eigenaar maupun bezitter melainkan hanya sebagai detentor atau houder untuk dan atas nama kreditor eigenaar".22

Sebelum berlakunya UU No. 42 Tahun 1999 tentang Jaminan Fidusia mengenai sifat accessoir dari perjanjian fidusia oleh Pitlo dikemukakan bahwa dengan diakuinya zekerheidseigendom (fiducia), tunduklah fidusia kepada ketentuanketentuan dari hak-hak kebendaan yang memberi jaminan. Karenanya dapat dilakukan penerapan secara analogi ketentuan-ketentuan hipotek dan gadai. Maka ini tidak lain berarti bahwa zekerheids eigendom dianggap merupakan piutang yang bersifat accessoir. Sri Soedewi memberikan penegasan bahwa: "Perjanjian fidusia adalah bersifat accessoir, adanya tergantung pada perjanjian pokok yang biasanya berupa perjanjian peminjaman uang di bank". ${ }^{23}$ Di dalam praktek perbankan perjanjian fidusia itu sering diadakan sebagai tambahan jaminan pokok manakala jaminan pokok itu dianggap kurang memenuhi. Adakalanya Fidusia juga diadakan secara tersendiri, dalam arti tidak sebagai tambahan jaminan pokok, yaitu: "Sebagaimana sering dipakai oleh para pegawai kecil, pedagang kecil, pengecer dan lainlain sebagai jaminan kredit mereka yang dimintakan pada bank". ${ }^{24}$ Adapun bentuk perjanjian Fidusia tidak terikat oleh bentuk tertentu. Untuk kredit-kredit dalam jumlah besar dan dengan tanggungan barangbarang yang berharga, maka biasanya perjanjian

\footnotetext{
${ }^{21}$ A. Hamzah dan Senjun Manulang. op.cit., h. 37.

22 ibid., h. 37.

${ }^{23}$ Sri Soedewi Masjchoen Sofwan. (1977). Beberapa Masalah Pelaksanaan Lembaga Jaminan Hapusnya Fidusia di Dalam Praktek dan Perkembangannya di Indonesia. Yogyakarta: FH UGM, h. 24.

${ }^{24}$ ibid., h. 26.
}

Fidusia dituangkan dalam akta notaris, misalnya berupa fidusia atas pabrik atau gedung perusahaan di atas tanah hak sewa atau hak pakai. ${ }^{25}$

Sebagai konsekuensi dari perjanjian accessoir apabila perjanjian Induk atau perjanjian pokok tidak sah atau karena sebab apa pun hilang berlakunya atau dinyatakan tidak berlaku karena berakhirnya perjanjian pokok, maka setara hukum perjanjian fidusia sebagai perjanjian accessoir juga ikut menjadi batal atau juga ikut berakhir. Pemberlakuan aturan ini mempunyai arti akta autentik yang berupa akta jaminan fidusia dapat gugur karena akta perjanjian utang yang dibuat di bawah tangan cacat hukum. Dalam hal piutang beralih kepada kreditor lain/baru, maka jaminan fidusia yang menjaminnya demi hukum ikut beralih kepada kreditor baru. Jaminan Fidusia bukan merupakan perjanjian yang berdiri sendiri tetapi keberadaannya atau hapusnya bergantung pada perjanjian pokoknya yang menimbulkan kewajiban para pihak Untuk memenuhi prestasi yang dapat dinilai dengan uang, walaupun perjanjian pokoknya dibuat secara autentik maupun di bawah tangan, baik dibuat di Indonesia maupun di luar negara Indonesia.

Sebagai suatu perjanjian accessoir, perjanjian akta jaminan fidusia memiliki sifat sebagai berikut: 1. sifat ketergantungan terhadap perjanjlan pokok; 2. keabsahannya semata-mata ditentukan oleh sah tidaknya perjanjian pokok; dan 3. sebagai perjanjian bersyarat, maka hanya dapat dilaksanakan jika ketentuan yang disyaratkan dalam perjanjian pokok telah dipenuh. ${ }^{26}$

Undang-Undang Nomor 42 Tahun 1999 tentang Jaminan Fidusia menegaskan secara jelas bahwa jaminan fidusia adalah agunan atas kebendaan atau jaminan kebendaan (zakelijke zekerheid, security right in rem) yang memberikan kedudukan yang didahulukan kepada penerima fidusia. Penerima fidusia memiliki hak yang didahulukan terhadap kreditor lainnya. Hak yang didahulukan dari penerima fldusia tidak hapus karena adanya kepailitan pemberi fidusia. Penegasan dimaksud menghilangkan keraguan dan pandapat bahwa jaminan fidusia tidak menimbulkan hak agunan atas kebendaan, melainkan hanya merupakan perjanjian obligatoir

\footnotetext{
${ }^{25}$ ibid.

${ }^{26}$ Gunawan Wijaya dan Ahmad Yani. (2001). Jaminan Fidusia. Jakarta: Raja Grafindo, h. 205.
} 
yang melahirkan hak yang bersifat "persoonlijk" (perorangan) bagi kreditor.

Keberadaan UUJF menegaskan bahwa: "Jaminan fidusia merupakan perjanjian ikutan atau accessoir dari suatu perjanjian pokok, artinya jaminan fidusia hapus demi hukum bilamana utang yang dijamin dengan jaminan fidusia hapus". ${ }^{27}$

\section{Perlindungan Hukum Debitor Dalam Menguasai Objek Jaminan Fidusia}

Hukum dibuat memiliki sifat dan fungsi hukum. Fungsi hukum mengenal hak jaminan yang memberikan perlindungan yang seimbang baik kepada debitor kreditor maupun kepada pihak ketiga yang mungkln akan tersangkut kepentingannya kepada hubungan antara kreditor dan debitor.

Keberadaan undang-undang pada prinsipnya hendak melindungi pihak/orang tertentu, sehingga hak tertentu yang diharapkan oleh para pihak tertentu bersebut diakomodir dan diberikan oleh undangundang. Penggunaan hak yang telah diberikan oleh undang-undang dikembalikan kepada para pihak yang hendak dilindungi untuk menggunakan atau tidak. Jika hak yang telah diberikan tidak digunakan maka ia tidak dapat menikmati keuntungan yang hendak diberikan oleh undang-undang.

Tujuan dan diadakannya perjanjian fidusia ialah: "Untuk penjaminan dan bukan untuk pemberian hak milik, dan jika terjadi kepailitan pada debitor maka semua piutang-piutang kreditor dapat ditagih dan barang-barang jaminan berada di luar boedel kepailitan". ${ }^{28}$ Perjanjian dengan Jaminan fidusia melahirkan hak yang zakelijk bagi kreditor, maka hak zakelijk tersebut dapat dipertahankan terhadap pihak ketiga dan benda-benda jaminan yang berada pada debitor masuk dalam boedel kepailitan. Untuk pemenuhan piutangnya kreditor dapat bertindak terhadap jaminan tersebut seolah-olah tidak terjadi kepailitan. "Kreditor memiliki kedudukan yang terkuat disebut "separatis", seperti halnya pemegang gadai dan hipotek, yang pemenuhan piutangnya harus lebih didahulukan dari kreditor-kreditor yang lainnya sehingga memiliki kewenangan untuk menjual atas kekuasaan sendiri terhadap benda-benda Jaminan manakala debitor tidak memenuhi kewajibannya". ${ }^{29}$

\footnotetext{
${ }^{27}$ Lihat Pasal 25 ayat (1) a UUJF.

${ }^{28}$ A. Hamzah dan Senjun. op.cit., h. 56.

${ }^{29}$ ibid., h. 58.
}

Sebaliknya jika kreditor yang pailit, mengacu pada prinsip bahwa jaminan sekedar obligatoir, maka konsekuensinya adalah hak-hak atas benda jaminan itu dapat dipertahankan terhadap pihak ketiga, jadi juga terhadap kurator kepailitan. "Kurator kepailitan tidak dapat menarik benda-benda tersebut (revindikatie) dari kekuasaan debitor, selama debitor tetap memenuhi kewajiban dengan baik, yaitu membayar hutang kepada kreditor". ${ }^{30}$ Debitor masih tetap dapat menguasai bendanya, memakainya, mempertahankannya terhadap kurator dan para kreditor si pailit. Benda-benda tidak jatuh dalam boedel kepailitan. Jika si debitor melunasi hutanghutangnya, maka ia akan memperoleh kembali bendanya yang dipakai sebagai jaminan. Namun jika debitor tidak melunasi hutang-hutangnya maka kurator kepailitan dapat menjual benda-bendanya kemudian sisanya setelah diperhitungkan dengan hutangnya dikembalikan kepada kreditor.

Pengaturan dalam Pasal 11 sampai Pasal 18 UUJF dimaksudkan untuk memberikan perlindungan hukum kepada pihak penerima fidusia. Oleh karena itu, undang-undang meletakkan kewajiban kepada penerima fidusia untuk melakukan pendaftaran Akta Jaminan Fidusia (AJF). Tidak terdaftarnya AJF berakibat tidak mempunyai kekuatan eksekutorial dan unsur pidananya hilang. Undang-undang jelas dibuat untuk menciptakan keadilan dan kesejahteraan melalui ketertiban dan kepastian hukum dengan pelaksanaan yang sederhana dan berbasis biaya murah.

\section{Kedudukan Hukum Debitor Dalam UUJF}

Pembangunan ekonomi, merupakan bagian dari pembangunan nasional, untuk mencapai masyarakat yang adil dan makmur berdasarkan Pancasila dan UUD 1945. Guna memelihara dan meneruskan pembangunan yang berkelanjutan, para pelaku pembangunan baik pemerintah maupun masyarakat, baik perseorangan maupun badan hukum, memerlukan dana yang besar. Kegiatan pembangunan akan berdampak pada meningkat pula kebutuhan terhadap pendanaan, sebagian besar dana yang diperlukan untuk memenuhi kebutuhan tersebut diperoleh melalui kegiatan pinjam-meminjam. Hal ini menjadi sebab perlu diimbangi dengan adanya ketentuan hukum yang

30 ibid., h. 59. 
jelas dan lengkap yang mengatur mengenai lembaga Jaminan. Sebelum adanya UUJF, jaminan fidusia diatur dalam yurisprudensi dan diatur secara parsial dalam Undang-Undang Rumah Susun serta UndangUndang Perumahan dan Pemukiman. Sehingga untuk memenuhi kebutuhan pembangunan nasional diperlukan hukum yang menjamin kepastian hukum serta mampu memberikan perlindungan hukum bagi pihak yang berkepentingan. Hukum perlu dibentuk yang memuat ketentuan yang lengkap mengenai jaminan fidusia dan jaminan tersebut perlu didaftarkan pada Kantor Pendaftaran fidusia sebagai dasar adanya kepastian hukum.

Sebelum adanya UUJF, objek Jaminan Fidusia adalah benda bergerak yang terdiri dari benda dalam persediaan (inventory), benda dagangan, piutang, peralatan mesin dan kendaraan bermotor. Oleh karena itu, guna memenuhi kebutuhan masyarakat yang terus berkembang, maka menurut UUJF, objek Jaminan Fidusia diberikan pengertian yang luas yaitu benda bergerak yang berwujud maupun tak berwujud, dan benda tak bergerak yang tidak dapat dibebani dengan hak tanggungan sebagaimana ditentukan dalam Undang-Undang Nomor 4 Tahun 1996 tentang Hak Tanggungan. Dalam UUJF, mengatur tentang pendaftaran Jaminan Fidusia guna memberikan kepastian hukum kepada para pihak yang berkepentingan. Pendaftaran Jaminan Fidusia memberikan hak yang didahulukan (preferen) kepada penerima fidusia terhadap kreditor lain karena jaminan fidusia memberikan hak kepada pihak pemberi fidusi untuk tetap menguasai benda yang menjadi objek jaminan fidusia berdasarkan kepercayaan, maka diharapkan sistem pendaftaran yang diatur dalam UUJF dapat memberikan jaminan kepada pihak penerima fidusia dan pihak-pihak yang mempunyai kepentingan terhadap benda tersebut.

Lembaga jaminan fidusia sesungguhnya sudah ada dalam masyarakat sejak zaman dulu, tepatnya pada zaman kerajaan Romawi dan digunakan oleh masyarakat hukum Romawi. Lembaga ini dikenal dengan nama Fidusia Cum Creditore janji kepercayaan yang dibuat dengan kreditor, isi perjanjiannya pemberi fidusia atau creditor tetap menguasai benda yang menjadi objek fidusia. Dengan tetap menguasai benda yang menjadi objek fidusia, maka pemberi fidusia atau debitor dapat menggunakan benda objek fidusia dimaksud dalam menjalankan usahanya dan Fidusia Cum Amico, tetapi dalam hal ini dimaksudkan sebagai pengangkatan seorang wakil untuk memelihara kepentingannya. Jadi, tidak ada penyerahan hak milik atau Jaminan utang sebagaimana dilakukan dalam pengikatan fidusia saat ini. ${ }^{31}$

Keberadaan praktek Jaminan Fidusia di Indonesia tidak dapat dilepaskan dari asas konkordansi. Hal ini dimulai sejak terbentuknya Negara Kesatuan Republik Indonesia pada tanggal 17 Agustus 1945, pemerintah Indonesia dengan asas konkordansi langsung mengkonversi peraturan perundangundangan yang diberlakukan oleh Pemerintah Hindia Belanda pada waktu itu sepanjang tidak bertentangan dengan tujuan kemerdekaan dan kepentingan nasional. Hal itu dapat dilihat dalam UUD 1945 dalam pasal peraturan peralihan. "Segala peraturan perundang-undangan yang ada masih tetap berlaku selama belum diadakan yang baru menurut undangundang dasar ini". ${ }^{32}$ Salah satu peraturan yang dikonversi dengan menggunakan asas konkordansi adalah FEO (Fiduciare eigendomsoverdracht).

Fiduciare eigendomsoverdracht merupakan pengalihan hak milik secara keperdataan merupakan rekayasa hukum dalam arti positif, karena aturan ini tidak terdapat pada KUHPerdata. Dalam KUHPerdata yang diatur adalah: "Lembaga Jaminan: hipotek dan gadai". ${ }^{33}$ Dalam praktik ada kebutuhan, untuk menjaminkan barang bergerak tanpa menyerahkan barang jaminan secara fisik. Jadi, secara tegas ada perbedaan yang cukup mencolok terhadap perbedaan fidusia, gadai dan hipotek, hal ini juga dikatakan oleh Gunawan Widjaya "untuk maksud tersebut tidak dapat digunakan lembaga gadai (yang mensyaratkan penyerahan benda) dan juga tidak dapat digunakan hipotek (yang hanya diperuntukkan terhadap barang tidak bergerak saja)". ${ }^{4}$

Jalan keluarnya dibuatkan rekayasa hukum untuk memenuhi kebutuhan masyarakat dalam praktilk seperti tersebut di atas, dengan jalan pemberian

\footnotetext{
${ }^{31}$ Munir Fuady. (2000). Jaminan Fidusia. Bandung: Citra Aditya Bakti, h. 8.

32 Undang-Undang Dasar Negara Republik Indonesia Tahun 1945 dan Perubahannya. (2009). Jakarta: Tandabaca, h. 45.

${ }^{33}$ Kitab Undang-Undang Hukum Perdata terjemahan Subekti \& Tjitrosudibio.

${ }^{34}$ Gunawan Widjaya dan Ahmad Yani. Jaminan Fidusia. op.cit., h. 25.
} 
jaminan fidusia dan diakui yurisprudensi, yang pada mulanya dianggap sebagai penyelundupan hukum. Rekayasa hukum berupa penyerahan kepemilikan benda tanpa menyerahkan fisik benda Jaminan yang dikenal dengan "constitutum posessorium".

\section{PENUTUP}

\section{Kesimpulan}

Dari uraian yang telah dipaparkan secara jelas dalam bab-bab sebelumnya maka penulis menyimpulkan sebagai berikut: Pertama, karakteristik lembaga jaminan fidusia, digunakan untuk menampung kebutuhan masyarakat akan pentingnya tambahan modal berupa dana dalam melakukan kegiatan usaha di bidang ekonomi dengan tetap menguasai benda modalnya itu digunakan dalam mempertahankan kegiatan usaha, sebagai agunan/jaminan memperoleh bantuan dana. Mengingat kedua lembaga jaminan yang ada dalam KUHPerdata yaitu gadai dan hipotek, tidak memberikan ruang dan tempat bagi masyarakat yang mengembangkan usaha dengan perolehan dana dari lembaga keuangan. Kalaupun jaminan dalam bentuk gadai, maka persyaratan utama bagi debitor untuk memperoleh dana harus menyerahkan benda kepada kreditor, hal ini debitor tidak dapat menggunakan benda tersebut untuk menjalankan aktifitas usaha yang berakibat tidak dapat melakukan pelunasan utang kepada kreditor, karena benda sebagai alat untuk menjalankan usaha harus diserahkan kepada kreditor. Kedua, kedudukan debitor dalam menguasai objek jaminan fidusia adalah kuat sekali karena benda jaminan secara de facto masih ada dalam penguasaan, secara de jure kepemilikan telah berpindah dengan jalan didaftarkannya benda jaminan itu di kantor pendaftaran fidusia. Dalam hukum benda penguasaan benda bergerak adalah kuat sekali karena sebagai bezitter maka seorang yang bertindak selaku bezitter benda bergerak sekaligus bertindak sebagai eigenaar/pemilik kebendaan berserak terebut sejalan dengan Pasal 1977 BW. Tetapi manakala dicermati berdasarkan asas spesialitas dan asas publisitas sudah menghasilkan suatu proses yang dapat melahirkan kepastian hukum yang prima dan adil.

\section{Rekomendasi}

Sejarah fidusia dilahirkan dari munculnya sengketa hukum yang dalam penyelesaian hukumnya dilakukan dengan dasar yurisprudensi, yang merupakan hasil penemuan hukum oleh hakim dalam memutus suatu sengketa, kemudian diadopsi menjadi UUJF. Dalam pasal-pasal UUFJ tersebut terdapat berbagai tumpang tindih di dalam pelaksanaanya. Karena itu penulis menyarankan kepada pemerintah untuk melakukan pembaharuan UUJF, supaya dapat memberikan perlindungan hukum bagi semua pihak yang terlibat dalam penggunaan UUJF, sehingga dapat mewadahi kebutuhan masyarakat bisnis utamanya kebutuhan dana, khususnya kalangan usaha mikro, usaha kecil, dan usaha menengah yang hingga saat ini merupakan kalangan usaha yang mampu bertahan dan bersaing dengan kalangan usaha besar. Perlunya pemerintah menggali rumusan peraturan pembaharuan UUJF dengan penggunaan bahasa hukum yang sederhana dalam pasal-pasal dalam UUJF, sehingga mudah dipahami oleh para pihak, yang berakibat pencapaian tujuan hukum yaitu kepastian hukum tidak dikurangi/dikebiri oleh akibat ketidakjelasan bahasa dalam setiap pasal yang ada dalam UUJF.

\section{DAFTAR PUSTAKA}

\section{Peraturan Perundang-undangan:}

Undang-Undang Dasar Negara Republik Indonesia Tahun 1945 dan Perubahannya.

Kitab Undang-Undang Hukum Perdata (KUHPerdata) (Burgerlijk Wetboek, Staatsblad 1847 Nomor 23).

Undang-Undang Republik Indonesia Nomor 4 Tahun

1996 tentang Hak Tanggungan Atas Tanah

Beserta Benda-Benda Yang Berkaitan Dengan Tanah. Lembaran Negara Republik Indonesia Tahun 1996 Nomor 42. Tambahan Lembaran Negara Republik Indonesia Nomor 3632.

Undang-Undang Republik Indonesia Nomor 10

Tahun 1998 tentang Perubahan Atas UndangUndang Nomor 7 Tahun 1992 tentang Perbankan. Lembaran Negara Republik Indonesia Tahun 1998 Nomor 182. Tambahan Lembaran Negara Republik Indonesia Nomor 3790.

Undang-Undang Republik Indonesia Nomor 42

Tahun 1999 tentang Jaminan Fidusia. Lembaran Negara Republik Indonesia Tahun 1999 Nomor 168. Tambahan Lembaran Negara Republik Indonesia Nomor 3889. 
Peraturan Pemerintah Republik Indonesia No. 21 Tahun 2015 tentang Tata Cara Pendaftaran Jaminan Fidusia dan Biaya Pembuatan Akta Jaminan Fidusia. Lembaran Negara Republik Indonesia Tahun 2015 Nomor 80. Tambahan Lembaran Negara Republik Indonesia Nomor 5691.

\section{Buku:}

Andi Hamzah dan Senjun Manullang. (1987). Lembaga Fidusia dan Penerapannya di Indonesia. Cet. Pertama. Jakarta: Ind-Hill Co.

Budi Untung. (2000). Kredit Perbankan di Indonesia. Yogyakarta: Penerbit Andi.

Etty Mulyati. (2016). Kredit Perbankan Aspek Hukum dan Pengembangan Usaha Mikro Kecil dalam Pembangunan Perekonomian Indonesia. Bandung: RefikaAditama.

Fajar Sugianto. (2014). Buku Hukum Economic Analysis of Law Seri Analisis Keekonomian tentang Hukum. Jakarta: Kencana Prenadamedia Grup.

Gunawan Wijaya dan Ahmad Yani. (2001). Jaminan Fidusia. Jakarta: Raja Grafindo.

H. Moch. Isnaeni. (2016). Pengantar Hukum Jaminan Kebendaan. Surabaya: Revka Petra Media.

H.TanaKamelo. (2004). Hukum Jaminan Fidusia Suatu Kebutuhan Yang Didambakan. Bandung: Alumni.

Hermansyah. (2005). Hukum Perbankan Nasional Indonesia. Jakarta: Prenada Media.

Mariam Darus Badrulzaman. (1994). Aneka Hukum Bisnis. Bandung: Alumni.

(2000). Beberapa Permasalahan Hak Jaminan. Jakarta: Yayasan Pengembangan Bisnis.
Muhamad Djumhana. (1996). Hukum Perbankan di Indonesia. Bandung: Citra Aditya Bakti.

Munir Fuady. (1996). Hukum Perkreditan Kontempore. (Cetakan Kesatu). Bandung: Citra Aditya Bakti.

Munir Fuady. (2000). Jaminan Fidusia. Cetakan Pertama. Bandung: Citra Aditya Bakti.

OP. Simorangkir. (1989). Kamus Perbankan. Jakarta: Bina Aksara.

R. Subekti dan R. Tjitrosudibio. (1983). Buergerlijk Wetboek (Kitab Undang-Undang Hukum Perdata/Terjemahan). Jakarta: Pradnya Paramita.

Sri Soedewi Masjchoen Sofwan. (1977). Beberapa Masalah Pelaksanaan Lembaga Jaminan Hapusnya Fidusia di Dalam Praktek dan Perkembangannya di Indonesia. Yogyakarta: FH UGM.

(1980). Hukum Jaminan di Indonesia Pokok-Pokok Hukum Jaminan dan Jaminan Perorangan. Yogyakarta: Bina Usaha.

Sudikno Mertokusumo. (1991). Mengenal Hukum (Suatu Pengantar). Yogyakarta: Liberty.

Undang-Undang Dasar Negara Republik Indonesia Tahun 1945 dan Perubahannya. (2009). Jakarta: Tandabaca.

Yusriyadi. (2009). Tebaran Pemikiran Kritis Hukum dan Masyarakat. Malang: Surya Pena Gemilang.

\section{Internet:}

http://blog.stie-mce.ac.id/tita/2014/08/31/prinsipprinsip-penilaian-kredit-6c-7p-3-r-apa-sihisinya/, diunduh tanggal 31 juli 2017.

http://romand3.wordpress.com/2007/07/30/peranpengusaha-dalam-perekonomian, Kompas.com, diakses tanggal 4 Januari 2017 jam 13.00 WIB. 